\title{
Sharing Economy Phenomenon in the Digitization Era
}

\author{
Lilia S. Revenko*a and Nikolay S. Revenko ${ }^{\mathrm{b}}$ \\ ${ }^{a}$ Moscow State Institute of International Relations (University) \\ of the MFA of Russia \\ 76 Vernadskogo, Moscow, 119454, Russia \\ ${ }^{b}$ Financial University \\ 49 Leningradsky, Moscow, 125993, Russia
}

Received 05.03.2019, received in revised form 01.04.2019, accepted 08.04.2019

The article examines foreign and Russian experience in the sharing economy development. The phenomenon of collaborative consumption of goods and services gained an impetus on the back of technological change mainly due to the digitization. Digital platforms have brought the narrow consumer market phenomenon to the global economy level and created prerequisites not only for enhancing the local exchange of temporarily free resources (physical, power, labour, recreational resources and others), but also for their cross-border movement. The high spreading speed of digital technologies and business models based on them, as well as the objectively existing time lag between the ongoing transformations and their evaluation at the theoretical level, create a pluralistic picture of the concepts of this phenomenon. A critical analysis of approaches practiced by experts from different countries to the sharing economy scope revealed a shift in emphasis between some traditional economic categories, generating a field for theoretical discussion. The delicate borderline between the sharing economy and normal business operations causes regulatory problems at national and international levels. Based on their own theoretical views, the authors define the key areas of the sharing economy development, identify current trends that determine the present changes: market growth, multiplication of collectively consumed items, acceleration of operational activities, optimization of the end users' income and expense. Advantages and disadvantages of sharing economy are also identified.

Keywords: sharing economy, digital platforms, optimizing resource usage, sectoral market structure, service content.

Research area: world economy.

Citation: Revenko, L.S., Revenko, N.S. (2019). Sharing economy phenomenon in the digitization era. J. Sib. Fed. Univ. Humanit. soc. sci., 12(4), 678-700. DOI: 10.17516/1997$1370-0416$.

(C) Siberian Federal University. All rights reserved

* Corresponding author E-mail address: 1.revenko@inno.mgimo.ru

ORCID: 0000-0002-1519-1183 (Revenko L.S.); 0000-0002-0359-5201 (Revenko N.S.)

This work is licensed under a Creative Commons Attribution-NonCommercial 4.0 International License (CC BY-NC 4.0). 


\section{Introduction}

The current stage of the world economy development is marked by multiple changes in the conditions and factors affecting the ratio of the market mechanism elements. This situation, defined primarily by technological change, is typical for shaping a new technological structure. Cross-cutting, or cross-industry, digital technologies can be undoubtably considered to be the driving force, powerhouse of the current technological change wave. Leadership of digital, or information, technologies in the group of convergent technologies defines the current stage of economic development as the digital economy era.

Although there are many definitions of digital economy, the authors prefer to rely on the wording of the UN Commission on Trade and Development (UNCTAD): "the application of internet-based digital technologies to the production and trade of goods and services" (UNCTAD, 2017: 156).

Rapidly developing comprehensive digitization of the world economy, along with other important trends, predetermines technological and organizational changes in the entire structure of relationships between the subjects of the global and domestic markets.

The "opportunity window" opened to optimize the use of resources at different levels, i.e. in different sectors, by individual economic entities, households and private persons, can be considered to be one of the digital economy phenomena. The full-fledged transformation of information and data into an economically significant resource alters the special aspects of economic activity. It is this digitization property that gave rise to the sharing economy phenomenon, also known as the share economy, collaborative economy, peer economy, collaborative consumption, access-based consumption. Thus, the study by the Organization for Economic Cooperation and Development (OECD), notes that the sharing economy "opens up new opportunities for consumers to access goods and services in different markets" (OECD, 2017: 6).

The purpose of this study is to analyse the theoretical and practical aspects of the sharing economy phenomenon.

\section{Theoretical framework}

Theoretical study of the economic aspects of digital economy as a whole and broken down to individual areas, including the sharing economy, is in the initial stage. The analysis of the standpoints of foreign and Russian researchers revealed that high subjectivism is typical for the current stage of the sharing economy development. This can be explained as follows: 
firstly, the proportion between "possession" and "disposition" in the market driven by the digitization has changed at the stage of supply of goods and services, and, what is crucial, the economic essence of these notions is balanced by psychological, social and technological factors;

secondly, boundaries between many categories and definitions, such as "rental" or "sharing", "service" or "technology", previously clearly understood in the scientific economic community, have turned blurred;

thirdly, there are problems in quantifying the volume of the sharing goods and services market, lack of common criteria and indicators for the statistical support of research in this area;

fourthly, the absence of clear borders between the digitization areas challenges the assessment of real benefits for producers and consumers of goods and services. No wonder that Klaus Schwab, Founder and Executive Chairman of the World Economic Forum, noted that the Fourth Industrial Revolution will have a fundamental impact on the world economy, which will be so far-reaching and multifaceted in nature that it will be almost impossible to separate one specific effect from another (Schwab, 2017: 43).

The sharing economy agenda has been developed by the world academic community over the past ten years, and some research experience has already been accumulated to structure concepts and standpoints. When analysing the sharing economy, it is advisable to rely on the expert opinions and records of relevant international organizations that collect advanced ideas and views of the digitization era.

At the theoretical level, differences are mainly focused on the sharing economy definition, scope, criteria for volume evaluation and market structure.

The first ideas and approaches to the problem were summarized and formulated in 2010 in the study by R. Botsman and R. Rogers, who substantiated the reasons for emergence of a new economic model and evaluated its prospects. The same study laid the groundwork for contradictory interpretations of the sharing economy concept. According to these researchers, there is a wide range of transactions (barter, exchange, lease, donation and lending) in three categories: "product service systems" (access to products or services without the need for owning the underlying assets); "redistribution markets" (reallocation of goods); and "collaborative lifestyles" (exchange of intangible assets), that falls under the sharing economy (Botsman \& Rogers, 2010: XV).

Now, almost a decade after the problem setting, this approach can be seen as excessively broad. Experts believe, inter alia, that the comparison with barter may be 
correct, "when users can directly exchange the services provided, for example, to rent a car, providing, in turn, housing for living" (Revenko et al., 2019: 66).

There are two ways of understanding the sharing economy today: broad and narrow. This is the scope where the expert opinions differ.

In the broad sense, the sharing economy includes all sale transactions using digital platform and other commercial activity if the parties are sellers and buyers themselves. For example, the sharing economy categories are broadly interpreted in the position paper of the World Economic Forum, that highlights the following scope areas: things redistributed from the place they are not needed to where they are needed, product service systems allowing to use a product without needing to own it, and collaborative lifestyle platforms allowing to share and exchange intangible assets such as time, skills, money, experiences or space (WEF, 2013: 7).

J. Schor takes roughly the same position. She believes that four categories, i.e. recirculation of goods, increased utilization of durable assets, exchange of services and sharing of production assets, fall into the sharing economy activity (Schor, 2014). R. Botsman defines the sharing economy as "an economy built on distributed networks of connected individuals and communities versus centralized institutions, transforming how we can produce, consume, finance, and learn" (Botsman, 2013).

The position of R. Belk is of theoretical interest. He believes that the collaborative consumption is "people coordinating the acquisition and distribution of resources for a fee or other compensation" (Belk, 2014b: 1597). He also makes a distinction between "true sharing" and "pseudo sharing" collaborative consumption. "True sharing", according to R. Belk, means "entailing temporary access rather than ownership, no fees or compensation, and use of digital platforms" (Belk, 2014a), and this is in line with the approach of this study' authors.

PricewaterhouseCoopers experts define the sharing economy as a model that "allows individuals and groups to make money from underused assets" (PwC, 2015: 5). J. Halmari, M. Sjöklint and A. Ukkonen define the sharing economy as "the peer-to-peer-based activity of obtaining, giving, or sharing the access to goods and services, coordinated through community-based online services" (Halmari, Sjöklint \& Ukkonen, 2015: 1).

L. Lessig believes that "of all the terms of exchange within the sharing economy, the single term that is not appropriate is money... Money in the sharing economy is not just inappropriate; it is poisonous" (Lessig, 2008: 118-119). This, however, is clearly contrary to the sharing practice. After all, if we exclude reimbursable 
operations, the activity of many digital platforms would not be attributed to the sharing economy.

In the narrow sense, the sharing economy encompasses the commercial activity that involves the provision of temporarily free goods or services by users to each other for a limited period of time. The key point of this interpretation is the absence of title transfer. K. Frenken, T. Meelen, M. Arets and P. van de Glind can be seen as supporters of this approach. They believe that in the sharing economy consumers (or firms) grant each other "temporary access to their under-utilized physical assets (idle capacity), possibly for money" (Frenken et al., 2015).

Oxford Living Dictionaries defines the sharing economy as "an economic system in which assets or services are shared between private individuals, either free or for a fee, typically by means of the Internet" (EOLD, 2019).

Diversity of opinions exists on the identification of the sharing economy subjects too. Some experts believe that these are all peer-to-peer participants in the process, the others affirm that the subjects are individuals only.

It is conspicuous that theoretical approaches to the assessment of the sharing economy, its scope, objects and subjects in different economic schools are formed at the transnational level. Studies of the sharing economy practices always consider regional and national distinctive features of this economic model.

An additional point is that few studies assessed the impact made by the sharing economy on the global economy sectoral structure and on the world trade volume. Thus, when analysing global demand changes in a number of sectoral markets, A. Spartak, a renowned Russian economist, notes the evidence of the sharing economy impact on the demand growth rate, when the desire to possess a durable good, e.g. a car, is inferior to its usability (Spartak, 2018: 13). Accordingly, this motivation of the end user impacts the demand volume and structure.

\section{Statement of the problem}

Considering the existing approaches, the authors believe, that the sharing economy is the multitude of relationships between end users, i.e. individuals and legal entities, regarding the use of temporarily free goods or services for a limited chronological period of time on a reimbursable or free basis without title transfer.

The problem of defining the essence of the sharing economy and its specific character in Russia and other countries, in our opinion, should be structured according to the methodology proposed below. 


\section{Methods}

The methodology of the study on the sharing economy phenomenon, applied in this article, is a comprehensive approach to identifying the distinctive interaction between elements of a complex socio-economic system. This methodology is based on the interdisciplinarity principle, relied on the historical, social and cultural transformation of the sharing economy practice in the $21^{\text {st }}$ century. Conceptually, this study focuses on the analysis of the sharing economy theories elaborated by the academic community and on practice-oriented works. To summarize the sharing economy practice, the author's method involves the use of their own classifications based on several criteria.

By the nature of meeting the needs, the collaborative consumption can be divided into the material, and cultural and intellectual; and its objects are classified into tangible goods and services. At the present stage the first group comprises real estate, vehicles, business class aircrafts, durable household goods, tools, books and other goods. Services in this classification can be represented by the following types: transport, leisure activities, content creation, streaming (file sharing).

Typology of digital platforms that allow for collaborative consumption is important for this method. D. Selloni identifies the following areas of the sharing economy: rental economy, peer-to-peer economy, on-demand economy, time banking and local exchange trading system, free/libre open source software, social lending and crowdfunding (Selloni, 2017: 18).

The authors focus on summarizing the empirical experience of individuals and economic entities on the collaborative consumption of goods and services in such sectors as transport, real estate, household goods, entertainment and communications, investments and services, mainly in the consumer-to-consumer $(\mathrm{C} 2 \mathrm{C})$ and peer-to-peer (P2P) sectors. Thus, the authors prioritize the group of methods for obtaining, processing and systematizing the empirical level knowledge with elements of comparative studies.

\section{Discussion}

Sharing is based on practical considerations. Getting involved into such relations, one party transfers his/her underused movable effects and real assets to another party for temporary use free of charge or for a reasonable fee without transfer of title. In its turn, it is more profitable for the other party in certain real-life situations not to buy a product or service, but to borrow it at a reasonable cost, without burdening him/herself with title registration and maintaining mobility. Such form of market relationships can also be interesting for business entities. 


\section{Main areas of the sharing economy operation}

Today, the sharing economy successfully operates in several areas, but the most interesting projects have been implemented in transport and real estate sectors, since expensive property rental can bring a significant income.

1) Transport. Rent a car with a driver, carsharing, ridesharing and delivery of goods are the main activity areas in this sector.

Car rental with a driver is one of the well-known high-income forms of the sharing economy. The most successful company working in the field of passenger transportation is Uber with the head office located in San Francisco, whose services are available in more than 600 cities in 65 countries. 75 million riders and 3 million drivers are registered on this platform, and 15 million trips are completed each day (Company Info, 2019).

The company, initially specialized in providing black luxury car service (UberBlack), has extended its activities to other areas, i.e. economy class taxi (Uber X), spacious cars with driver (UberSUV and UberXL), food delivery (UberEATS) and more. This entailed $\$ 72$ billion Uber market value in February 2018 (Schleifer, 2018), and there are plans to increase it to $\$ 120$ billion in 2019. If Uber succeeds, it will cost two times more than Tesla electric car manufacturer (Guardian, 2018), and will be closer to the value of Ford Company estimated at $\$ 143.9$ billion in June 2018 (Dennison, 2018).

Its main competitor in the United States is also a fast-growing Lyft company with the income that increased from $\$ 300$ to $\$ 563$ million in the third quarter of 2018 compared to the same period of 2017 (Barinka \& Newcomer, 2018), but it loses to Uber both in the number of trips and territorial coverage. By comparison, 436 thousand trips were made in New York in August 2018 with Uber cars, 275 thousand with city taxi and 122 thousand with Lyft cars (Iqbal, 2019).

Curb with 35 thousand cars connected in 60 U.S. cities is the third platform operating in this sector (Who are Uber's Biggest..., 2018).

Similar companies are established in other countries, for example, Didi Chuxing in China (\$52 billion market value in March 2018), Ola in India (\$3.7 billion), Grab in Singapore and six other Southeast Asian countries (\$6 billion), GoJek in Indonesia ( $\$ 1.8$ billion), Kabbee in the UK (Saiidi, 2018). To call a car with driver in Germany, many citizens use Mytaxi platform, which extended its activities to Spain, Switzerland, Poland, the UK, the USA and other countries.

Uber came to Russia in 2013, but merged its business with Yandex.Taxi in July 2017. This merge resulted in $36.6 \%$ in the joint capital for Uber, $59.3 \%$ for Yandex. 
Taxi and $4.1 \%$ for staff members (Khudaverdian, 2017). The total share of aggregators in the Russian market of passenger transportation by car with driver was estimated as $32.8 \%$ in June 2017. RuTaxi (commercial brands Vezet and Leader), Fasten (Saturn and Red Taxi), Yandex.Taxi, Maxim, Gett and Uber are the leading players there. The Analytical Centre under the Government of the Russian Federation estimated the share of the first two companies was $12.3 \%$ of the market in this period of time, Yandex.Taxi and Uber $10.4 \%$, Maxim $7.6 \%$, Gett $2.5 \%$ (Analytical Centre, 2018). A very active Citymobil can be noted as a new platform.

Expert opinions differ on carsharing, i.e. rental of temporarily free vehicles from individuals or legal entities. Supporters of the narrow approach believe that only cars that were purchased for personal needs, but are temporarily unused, fall under this activity area. Turo and Getaround (USA), Drivy and Ouicar (France), partner of the French National Railway Company, can be mentioned as examples of platforms involved in such activity.

Such carsharing is already quite popular abroad today. For example, more than 350 thousand cars and 10 million users in 56 countries are registered on Turo now (Turo, 2019), and 30 thousand cars and more than 1 million users on Ouicar (Ouicar, 2019).

As of April 6, 2019, 879 cars and 3,838 users were registered on Russian DARENTA platform (DARENTA, 2019), that positions itself as carsharing, rental for private owners who let their cars on lease with comprehensive and collision insurance. Compared to January 2018, the number of registered cars and users decreased respectively by 122 vehicles and 1709 persons, which proves that the service does not take root in Russia.

The lease revenue of car owners varies depending on the country, car and rental duration. Experts of Turo platform estimate the average value as $\$ 500$.

Researchers who endorse the broad interpretation of the sharing economy scope, believe that it also encompasses another type of carsharing, i.e. short-term car rental with per-minute payment. As of October 2016, this service was available in 46 countries, with roughly 15 million members sharing over 157 thousand vehicles (Shaheen, Cohen \& Jaffe, 2018b).

Asia, the largest carsharing region, accounts for $58 \%$ of worldwide members and $43 \%$ of cars. Europe, the second largest market, accounts for $29 \%$ of global membership and $37 \%$ of world fleet deployed. Germany, Spain, France, the UK, Italy, the Netherlands, Austria and Russia are the major ones in Europe. For example, as of January 1, 2018, the number of carsharing users in Germany accounted 2.11 million 
persons (The Number of Registered..., 2018), while the overall population of the country is 82.4 million people (Germany Population, 2019).

As of October 2016, one-way carsharing accounted for $26.0 \%$ of global fleet deployed and $31 \%$ of global membership, and roundtrip carsharing accounted $74 \%$ and $69 \%$ respectively (Shaheen, Cohen \& Jaffee, 2018a: 1). Thought the station-based lease is mainly used for the time being ( $74-83 \%$ of the market), more European companies become free-floating operators (17-26\%), mainly in densely populated areas (Carsharing Market Analysis, 2018). In Germany station-based operators counted 10,050 vehicles at 5,000 stations, and the free-floating ones had 7,900 vehicles (The Number of Registered..., 2018).

The largest companies operating in several countries are Car2Go, DriveNow and Zipcar. Communauto, Enterprise CarShare, Liftshar.com and Flinkster can be mentioned too.

Carsharing emerged in Russia in 2013 is developing at a rapid pace. If in June 2017 there were 5 companies in Moscow providing such a service, in February 2019 there were 14 operators already (Kak pol'zovat'sia karsheringom, 2019). Although this carsharing is available in many Russian cities today, $85 \%$ of the fleet are based in Moscow (Posypkina, Balenko \& Balashova, 2018), and its rapid growth occurred when the payment for parking was imposed.

It should be noted that car producers and standard rent-a-car companies offer this service too. Thus, Europcar has launched several projects, DriveNow is owned by $B M W$, and Zipcar is a subsidiary of Avis Budget Group.

New carsharing projects also emerge, such as, for example, electric vehicles shortterm rent project. The French Bolloré Group, which provides such cars for rent in Indianapolis, USA, through the BlueIndy platform, is the pioneer of this service. The same cars are available for rent in Paris, Bordeaux and Lyon. Electric and hybrid vehicles are increasingly used in German carsharing. As of early 2018, their share accounted for 10.3 per cent (The Number of Registered..., 2018).

Ridesharing or carpooling, i.e. ride-hailing service, is very promising. BlaBlaCar allowing to hitch a ride or to find a fellow traveller, is the best-known platform operating in this sector. 20 million persons make their trips quarterly through this website, and the company counts 65 million users, including 15 million in Russia (Korotko o BlaBlaCar, 2019).

Karzoo, created by $h 2 a$ Luxembourg company, that provides its services in Austria, Belgium, the UK, Germany, Luxembourg, the Netherlands, France and Switzerland, is another well-known international platform functioning in this sector. The American 
Carma, French IDVroom and La roue verte, Russian Dovezu can be noted as national platforms.

Delivery of goods. FretBay satisfies the needs of people looking for vehicles to transport their goods to other cities in many EU countries. Customers place information about the cargo volume, its nature, transportation dates and destination on this platform, and the vehicles owners directly contact them to agree on delivery terms and conditions. FretBay created a specialized platform MyBoxMan in 2016 that allows to find a courier for short-distance goods delivery.

2) Real estate. Airbnb is the best-known platform operating in this field. Its services of short-time apartments renting in the private sector are available in 81 thousand cities in 191 countries (Fact Facts, 2019). Experts estimated its market value as \$38 billion in May 2018 compared to \$25 billion in December 2015 (Carson, 2015). 4.2 million housings were registered on this platform at 2017 year-end, and 80 million persons used its services in 2016 (Trefis, 2018).

HomeAway is another well-known platform to rent flats from owners. In addition, there are platforms, for example, LiquidSpace, that specialize in leasing office space.

Airbnb, HomeAway and other platforms operating in this sector of the sharing economy are attractive because they help their users find accommodation at a lower price there compared to the hotel. Moreover, the apartments have a kitchen equipped with household appliances to save money on food. At the same time, customers face some inconveniences, such as longer booking confirmation compared with hotels and the need to provide personal data to the platform.

The hospitality network, also known as hospitality exchange, accommodation sharing, home stay network, hospitality service, where people can find free short-term accommodation, is also considered as a part of the sharing economy. As a rule, these services are focused on network communities whose members provide accommodation to each other while traveling.

Hospitality Club, Globalfreeloaders, CouchSurfing and Bewelcome are the best knows platforms operating in this sector. Moreover, there are several platforms focused on groups of people according to their interests. Thus, cyclists can find shelter through WarmShowers, and Esperanto practitioners exchange visits through Pasporta Servo. $W W O O F$ allows to find a farm engaged in organic production to work there for some time in exchange for free accommodation and meals.

3) Household goods, furniture and equipment. Due to the low cost of leased items, this sharing economy area is not as effective as rental of cars and apartments. 
Taking into account the goods to share, such platforms mainly limit their activities to the territory of one state. Thus, Zilok, whose motto is "Rent anything", operates in the United States, Fat Lama - in the UK, Peerby, operating a peer-to-peer service for products that people can share or request from persons in their neighbourhood, in the Netherlands. Spinlister available in 4 American cities, London and Amsterdam is an exception.

Russian RENTMANIA platform is designed for free placement of advertisements for lease of personal effects and search for those who need them.

Several platforms are focused on a specific circle of people. Thus, the rental of bicycles and other sports equipment is the main activity area of the above mentioned Spinlister, and people can find in the U.S. a temporary shelter for pets for the period of their holiday or business trip through DogVacay.

4) Entertainment and communications. Joint execution of projects such as software development, digital content creation and sharing, also fall under the sharing economy. The development of operating systems based on Linux kernel is an example of joint software development. YouTube, where users upload, view and share video files, is the most popular video hosting platform. Users share photos and videos on Instagram, and jointly draft and edit texts on Wikipedia. They can also compete with each other in different games on a number of sites.

People use BitTorrent-clients, peer-to-peer file-sharing programmes and applications, download managers (Shareman, MediaGet, eMule, eDonkey2000, Gnutella, Shareaza and more) to exchange films, audios, software, games and other digital content.

5) Investments. Attracting financial resources through crowdfunding helps to create films, music, video games, comics and to implement other expensive projects. Kickstarter created in 2009 can be referred to as an example of the sharing economy of this kind. As of February 21, 2019, 158179 projects for the total amount of \$4.13 billion were financed through this crowdfunding platform. 15.8 million backers took part in the fundraising (Kickstarter, 2019). Indiegogo, Patreon, PledgeMusic, RocketHub and more are other well-known platforms for the support of technological, design and creative projects on the crowdfunding basis. AngelList facilitates the financing of new start-ups.

Planeta.ru and Boomstarter.ru are similar to Kickstarter in Russia. As of April 6, 2019, more than 5,000 projects amounting to a total of RUB1 billion were implemented on the first platform (Planeta, 2019), and 1,877 projects of RUB376 million were launched on the second one (Boomstarter, 2019). 
6) Services. Based on the sharing economy concept, it comprises such activities as search for people to hang armoires and chandeliers, clean and repair apartments, perform other various works. Individuals and legal entities use Handy, TaskRabbit, Airtasker, Profi and other similar sites to place information about the work to be performed, and professionals advertise services they offer.

New sectors of the sharing economy are also emerging, such as rental of business aircraft for charter flights, for example, to ski or sea resorts, especially in the peak, since the cost of passenger seats on this kind of flights is lower than on regular ones.

Experts who endorse the broad interpretation of the sharing economy scope, in addition to the above mentioned car rental with per-minute payment, assert that it also encompasses other activities, such as fundraising for treatment of seriously ill patients, subsidizing education, providing assistance to people affected by natural disasters (GoFundMe, CrowdRise, Razoo, Miloserdie, Life Line and other funds), free distribution of unnecessary items and surplus food (Leftoverswap, HouseHold Goods, Latest FreeStuff, Food For Free, Food for the Poor, Darudar and more).

Loans granted to individuals by individuals for car purchase, wedding organization, home improvement etc. are also included into the scope of the sharing economy. British platform Zopa, for example, is used for such purposes (Allen \& Berg, 2014: 9-10).

Search for a job and business networking form other scopes of activities. Monster, as well as Upwork, formerly oDesk, global freelancing platform developed to connect businesses and independent professionals for remote collaboration (Cullen \& Farronato, 2018; Norton \& Golden, 2015), are examples of the first activity, LinkedIn - of the latter.

Some experts believe that audio and video streaming services (such as Spotify), that give online access to movies, songs and other digital content free of charge or for a small fee, are a part of the sharing economy too. They also suppose that the sharing economy encompasses online sale and purchase of goods, since platforms operating in this sector connect buyers and sellers. For example, eBay facilitates C2C and B2C sales through its website (Cullen \& Farronato, 2018), and Kidizen is a peer-to-peer marketplace to buy and sell children's items (PwC, 2015: 21). There are also specific services, such as Mosaic and Yeloha, allowing people to invest in solar energy or to receive alternative energy.

However, this broad interpretation of the sharing economy is criticized by the narrow approach supporters. They note, in particular, that Zipcar operates like an ordinary short-term car rental company (Schor, 2014), and this platform is a pure reseller (Codagnone \& Martens, 2016: 9). Fundraising is a charitable activity that does 
not fall into the sharing economy scope. Job search and business networking platforms serve to facilitate cooperation between professionals.

As for outsourcing platforms and streaming services, we believe that a digital content source should be taken as a location. If the platform is used to connect individuals, this service falls into the sharing economy, and if it is provided by specialized companies, this is a business activity.

Finally, it is unlikely that selling platforms fall under the sharing economy, because they are used to sell equipment and goods that are not temporarily free, and the property in goods is transferred due to this operation.

\section{Basic functioning principles of the sharing economy}

As noted above, the sharing economy operates through platforms designed to facilitate exchange of commodities between producers and consumers. Availability of high-speed networks is an essential condition for their successful functioning, as well as for the digital economy as a whole. That is why this problem is raised by all national strategies, programs and action plans for the development of the digital economy (Revenko \& Revenko, 2017).

Creating a platform is always a big risk. Its main functions include attracting clients, coordination, providing tools and services, defining rules and standards. In case of failure of a single segment, the platform inevitably faces difficulties (Moazed \& Johnson, 2019: 142).

The user network is the main value of the platform. To be profitable, the platform needs to reach a point where its value exceeds the cost of joining it. At the initial stage of operation, the value of connecting the platform is negative due to the small number of users and the need to sign up. The platform becomes a success only after it reaches a critical mass (Moazed \& Johnson, 2019: 217). Many platforms that failed to do so had to close.

Reputation that encourages customers to use the platform is an important condition for success. The mistake of many platforms was poor quality of services or a big number of fake accounts that repelled many users.

Since platforms connect unfamiliar people, rating and trust are the basic principles of their functioning. Ratings compiled on the basis of customer references intend to assess the quality of services provided and their conformity with the description available on the website, for example, of the rented apartment. Ratings used by Uber, Lyft, Gett and other aggregators encourage the good drivers who keep their cars clean, through the system of order distribution and bonuses. Handy, TaskRabbit, Profi 
and other platforms assess the competence of cooperating professionals. Functional efficiency of the platform and positive user feedback form the trust that encourages people to use it.

Another risk is that an interesting idea may sometimes appear to be unattractive for users. For example, it is more convenient for many users to order a new product with house-to-house delivery than to waste time and travel for rented goods to another city district and then to return it. For this reason, SnapGoods and a number of other similar websites were closed. In May 2018, A. Meshkovsky, the head of Rentmania service, announced his plans to transfer the service to the United States due to the lack of a financing system and the required number of investors in Russia (Mikhailova, 2018).

Since platform maintenance implies certain expenses, users usually pay a fee which may vary in amount. For example, Yandex.Taxi drivers working under Economy, Comfort, Children and Minivan tariffs in Moscow pay $18 \%$ of the trip cost, plus RUB5.50 for use of the software from each order and VAT $20 \%$. Accordingly, the total fee is $24.5 \%$ of the trip cost (Komissiia Iandex.Taksi i parka, 2018). Airbnb usually charges the owner $3 \%$ of the booking cost, and guests pay $0-20 \%$ depending on the length of stay and the rented flat (Chto takoe sbor..., 2019).

\section{Sharing Economy: Pros and Cons}

The sharing economy has great advantages. The main advantage is the ability to connect a large number of users to meet their needs. As a consequence, people get access to a wide range of goods and services at a variety of prices, including low ones. Moreover, people have an additional opportunity to apply their skills in practice, underused resources are involved into circulation, and new pricing models are shaped.

Digital platforms reduce transaction costs. Development of the sharing economy is especially beneficial to small and medium-sized enterprises, as they can hire freelance workforce to fulfil specific tasks.

At the same time, the sharing economy has a number of disadvantages. For example, passengers of cars rented through aggregators, guests of apartments in the private sector, drivers of rideshare cars face a personal safety problem. This is evidenced by cases of rude behaviour of drivers and even physical violence. It is an empirical fact that it is difficult to prosecute car aggregators because drivers are not their staff members. They only facilitate drivers and passengers to find each other.

Since the platforms are not able to control all users, the fraud threat is quite real. Freelance workers are often paid lower than staff members, and this is fraught with a 
decrease in their wages. Some per-minute car renters drive aggressively, trying to save money, challenging traffic safety on the roads.

Many traditional companies that have been in the market for decades, express their concern about the new competitors and believe that they undermine their business. As a consequence, the sharing economy actors are often accused of violating the applicable law. For example, hotels accuse Airbnb of circumventing national laws and security standards.

On the one hand, authorities should ensure that market forces drive firms to innovate (Ranchordas, 2015: 41), avoid erosion of legal and regulatory environment and protect consumer rights (Sunil \& Noah, 2015: 8). On the other hand, they have to respond to complaints of traditional companies and make decisions that restrict operation activity of the sharing economy platforms. For example, since 2016 landlords in New York are fined for advertising their housing on Airbnb and other similar websites for rental of less than 30 days (Welch, 2016), and in Berlin daily rent of apartments through Airbnb is banned (Robertson, 2016).

In accordance with the law of 2014, in 2015 in France Uber had to close its UberPop service for non-professional private car drivers. Since then, this service has been discontinued in all EU countries except for Poland, Romania and the Czech Republic (AFP, 2018).

Social security of persons cooperating with the platforms is a critical problem. Thus, Uber refers to its drivers as partners, because they work for themselves under the schedule they establish themselves. Accordingly, they are not eligible for health insurance, paid leave and other social benefits granted to staff members and cannot form trade unions. Moreover, they may find themselves in a difficult situation when they reach the age of retirement.

In 2018, the UK Court of Appeal left standing the UK employment tribunal decision of 2016, that qualified drivers as workers, not self-employed. This means that drivers are entitled to holiday pay, minimum wage and other benefits (Lomas, 2018). In January 2019, Paris Court of Appeal resolved that the partnership contract signed by Uber with drivers is a contract of employment (Commarmond, 2019).

\section{Sharing economy vs normal business operations}

As noted above, experts express different views on what activities fall under the sharing economy. The assessment, however, is even more difficult given the subtlety of the boundary between the sharing economy and commercial activity. Thus, not only 
the owners of private cars, but also taxi companies cooperate with Uber, Yandex.Taxi and other aggregators. Moreover, many individuals buy cars and real assets not for personal use, but to draw income, and this should be classified as business operations (Revenko, 2017: 109).

It is also difficult to identify whether a painter or a plumber provide their service out of duty or this is their regular income. Crowdfunding situation is even more complicated, since co-financing can be provided as a voluntary donation, say, to help a popular band to release an album, or to receive some income if the project is successful.

\section{Conclusion}

Collaborative consumption of goods and services cannot be considered a fundamentally new economic phenomenon. The use of household items in a certain order has been a common practice throughout all stages of human history in socially cohesive communities, and it still occurs in this archaic form. However, new forms of relationships of market actors have emerged in the modern post-industrial society at the stage of the world economy digitization, and they are based on the opportunities provided by technological transformations, primarily the introduction of digital platforms.

Conceptually, the sharing economy as one of digitization areas is based on such basic components increasing the efficiency of shared resources, green consumerism, socio-cultural and psychological advantages of access to a product without the transfer of title.

Rapid development of the sharing economy practice, expansion of areas, objects and access methods to a commodity without the transfer of title, constantly supply new empirical data for theoretical reflection. This explains the pluralism of opinions and the flexibility of theories of collaborative consumption of goods and services.

Diversification of resources and property assets shared by actors, growth of marketplace in the volume, acceleration and simplification of the transaction process, optimization of the income and expenditure structure of end users can be considered to be current trends in the development of the sharing economy.

The socio-economic success of the sharing model is primarily explained by the significant potential of underused resources in certain consumer sectors, i.e. physical, labour force, investment, power, space, recreation and others. Transaction cost reduction is another powerful incitement to the development of the sharing economy. If these factors are available, and the sharing economy continues its rapid development, 
the operational principles of this model can be expected to penetrate an increasing number of industries.

\section{References}

About Turo (2019). Available at: https://turo.com/about (accessed 19 February 2019).

Analytical Centre (2018). In Issledovanie rynka taksi [Taxi Market Study]. Moscow, Analytical Centre for the Government of the Russian Federation, 34 p. Available at: http://ac.gov.ru/files/content/15801/issledovanie-taksi-2018-pdf.pdf

AFP(2018). In New setbackfor Uber before the EUjustice, that gives reason to France [Nouveau revers pour Uber devant la justice de l'UE, qui donne raison à la France]. Available at: https:/www.lepoint.fr/high-tech-internet/nouveau-revers-pour-uberdevant-la-justice-de-1-ue-qui-donne-raison-a-la-france-10-04-2018-2209487_47.php (accessed 22 February 2019).

Allen, D., Berg, C. (2014). The Sharing Economy. How Over-Regulation Could Destroy an Economic Revolution. Melbourne, Institute of Public Affairs, 39 p.

Barinka, A., Newcomer, E. (2018). Uber Valued at $\$ 120$ Billion in an IPO? Maybe. 17 October 2018. Available at: https://www.bloomberg.com/news/articles/2018-10-16/ uber-valued-at-120-billion-in-an-ipo-maybe (accessed 12 February 2019).

Belk, R. (2014a). Sharing versus pseudo-sharing in web 2.0. In Anthropologist, 18(1), 7-23.

Belk, R. (2014b). You Are What You Can Access: Sharing or Collaborative Consumption Online. In Journal of Business Research, 67, 1595-1600.

Beutin, N. (2017). Share Economy. The New Business Model. PwC, 58 p.

Boomstarter (2019). Available at: http://boomstarter.ru/ (accessed 6 April 2019).

Botsman, R. (2013). The sharing economy lacks a shared definition. Available at: https:/www.fastcompany.com/3022028/the-sharing-economy-lacks-a-shareddefinition (accessed 10 February 2019).

Botsman, R., Rogers, R. (2010). What's mine is yours: The rise of collaborative consumption. New York, Harper Collins, 2010, 304 p.

Carsharing Market Analysis: Growth and Industry Analysis (2018). Available at: http://movmi.net/carsharing-market-growth/ (accessed 20 February 2019).

Carson, B. (2015). Airbnb just confirmed a massive \$1.5 billion round that makes it the third-highest valued start-up in the world. Business Insider. Available at: http://www. businessinsider.com/airbnb-15-billion-round-2015-12 (accessed 18 February 2019). 
Chto takoe sbor za uslugi Airbnb? [What Is the Airbnb Service Fee?] (2019). Available at: https://www.airbnb.ru/help/article/1857/what-is-the-airbnb-service-fee (accessed 13 February 2019).

Codagnone, C., Martens, B. (2016). Scoping the Sharing Economy: Origins, Definitions, Impact and Regulatory Issues. Brussels, Joint Research Centre of the European Commission, 32 p.

Commarmond, L. (2019). Judicial Jaws tighten over Uber [L'étau judiciaire se resserre sur Uber]. Available at: https:/www.lesechos.fr/economie-france/social/ 0600496871478-letau-judiciaire-se-resserre-sur-uber-2235660.php\#xtor=RSS-37.php (accessed 22 February 2019).

Company Info. (2019). Available at: https://www.uber.com/en-GB/newsroom/ company-info/ (accessed 6 April 2019).

Cullen, Z., \& Farronato, C. (2018). Outsourcing Tasks Online: Matching Supply and Demand on Peer-to-Peer Internet Platforms. Available at: https://www.hbs.edu/ faculty/Publication\%20Files/Cullen_Farronato_201802_9bd121ca-e09d-4e3c-8efbdd6ed973cd5d.pdf (accessed 21 February 2019).

DARENTA (2019). Available at: https://darenta.ru/ (accessed 6 April 2019).

Dennison, S. (2018). How Much Is Ford Worth? Available at: https://www. gobankingrates.com/making-money/business/how-much-is-ford-worth/ (accessed 19 February 2019).

EOLD. Sharing Economy (2019). English Oxford Living Dictionary. Available at: https://en.oxforddictionaries.com/definition/sharing_economy (accessed 9 February 2019).

Fact Facts (2019). Available at: https://press.airbnb.com/fast-facts/ (accessed 15 February 2019).

Frenken, K., Meelen, T., Arets, M., van de Glind, P. (2015). Smarter regulation for the sharing economy. Available at: https://www.theguardian.com/science/politicalscience/2015/may/20/smarter-regulation-for-the-sharing-economy (accessed 28 February 2019).

FTC (2016). The "Sharing" Economy. Issues Facing Platforms, Participants \& Regulators. A Federal Trade Commission Staff Report. Washington D.C., Federal Trade Commission, 95 p. Available at: https://www.ftc.gov/system/files/documents/ reports/sharing-economy-issues-facing-platforms-participants-regulators-federaltrade-commission-staff/p151200_ftc_staff_report_on_the_sharing_economy.pdf economy 
Germany Population (2019). Available at: http://www.worldometers.info/worldpopulation/germany-population/ (accessed 20 February 2019).

Guardian (2018). Uber Targets \$120bn Valuation for 2019 Flotation - Report. Available at: https://www.theguardian.com/technology/2018/oct/16/uber-targets-120bnvaluation-2019-flotation-report (accessed 19 February 2019).

Halmari, J., Sjöklint, M., Ukkonen, A. (2015). The Sharing Economy: Why People Participate in Collaborative Consumption. In Journal of the Association for Information Science and Technology, 67(9), 1-13. DOI: 10.1002/asi. Available at: https://people. uta.fi/ kljuham/2015-hamari_at_al-the_sharing_economy.pdf (accessed 18 February 2019).

Iqbal, M. (2019). Uber Revenue and Usage Statistics. Available at: http://www. businessofapps.com/data/uber-statistics/ (accessed 15 February 2019).

Kak pol'zovat'sia karsheringom [How to Use Carsharing] (2019). Available at: https://www.mos.ru/otvet-transport/kak-polzovatsya-karsheringom/ (accessed 20 February 2019).

Khudaverdian, T. (2017). Iandeks.Taksi i Uber poedut vmeste [Yandex.Taxi and Uber Will Go Together]. Available at: https://yandex.ru/blog/company/130717 (accessed 20 February 2019).

Kickstarter (2019). Stats. Available at: https://www.kickstarter.com/help/ stats?ref=global-footer (accessed 16 February 2019).

Komissiia Iandex.Taksi i parka [Fee of Yandex.Taxi and the Park] (2018). Available at: https://taxinomerok.ru/komissiya-jandeks-taksi-i-parka (accessed 21 February 2019).

Korotko o BlaBlaCar [BlaBlaCar in Brief]. (2019). Available at https://blog. blablacar.ru/about-us (accessed 19 February 2019).

Lessig, L. (2008). Remix: Making Art and Commerce Thrive in the Hybrid Economy. New-York, Penguin Press, 2008, 352 p.

Lomas, N. (2018). Uber Loses Another Appeal Against Drivers' Right in the UK. Available at: https://techcrunch.com/2018/12/19/uber-loses-another-appeal-againstdrivers-rights-in-uk/ (accessed 22 February 2019).

Mikhailova, L. (2018). Glava servisa arendy veshchei Rentmania reshil perevezti servis $v$ SSHA iz-za otsutstviia finansirovaniia $v$ Rossii [Head of Rentmania Rental Service Decided to Move the Service to the USA Because of Lack of Funding in Russia]. Available at: https://vc.ru/flood/38904-glava-servisa-arendy-veshchey-rentmaniareshil-perevezti-servis-v-ssha-iz-za-otsutstviya-finansirovaniya-v-rossii (accessed 20 February 2019). 
Moazed, A., Johnson, N.L. (2019). Platforma. Prakticheskoe primenenie revoliutsionnoy biznes-modeli [Modern Monopolies. What It Takes to Dominate the 21st Century Economy]. Moscow, Alpina Publisher, 288 p.

Norton, J.J., Golden, J.M. (2015). Reputation Inflation: Evidence from an Online Labour Market. Available at: https://pdfs.semanticscholar.org/59d6/e24bf80c01384d5 ce8a64e1582208b8b7072.pdf?_ga=2.52568431.696754453.1550749584-773766585. 1550749584 (accessed 21 February 2019).

OECD (2017). Trust in Peer Platform Markets: Consumer Survey Findings. OECD Digital Economy Papers, 263, 76 p. Available at: https://www.oecd-ilibrary.org/ docserver $/ 1$ a893b58-en.pdf?expires $=1550066388 \& \mathrm{id}=\mathrm{id} \&$ accname $=$ guest $\&$ checksum=980514974F496D2051CA33D41A9626E9.

Ouicar (2019). In Rent a Car in Two Steps [Louer la voiture à deux pas]. Available at: https://www.ouicar.fr/ (accessed 14 February 2019).

Planeta (2019). Available at: https://planeta.ru/about (accessed 6 April 2019).

Posypkina, A., Balenko, E., Balashova, A. (2018). Kak rynok karsheringa v Moskve okazalsia samym bystrorastushchim [How the Carsharing Market in Moscow Became the Most Rapid-Growing]. Available at: https://www.rbc.ru/technology_and_ media/27/09/2018/5bab94a69a79474169e307c1 (accessed 21 February 2019).

$P w C$ (2015). The Sharing Economy. PricewaterhouseCoopers LLP, 30 p. Available at: https://www.pwc.com/us/en/technology/publications/assets/pwc-consumer-intelligenceseries-the-sharing-economy.pdf

Ranchordas, S. (2015). Does Sharing Mean Caring? Regulating Innovation in the Sharing Economy. Tilburg, Tilburg University, Tilburg Law School, 63 p.

Revenko, L.S. Perskaya, V.V., Kholopov, A.V. et al. (2019). Mezhdunarodnye ekonomicheskie otnosheniia: realii, vyzovy i perspektivy [International Economic Relations: Realities, Challenges and Prospects]. Moscow, MGIMO-University, 750 p.

Revenko, L., Revenko, N. (2017). Mezhdunarodnaia praktika realizatsii programm razvitiia tsifrovoy ekonomiki: primery SSHA, Indii, Kitaia i ES [Global Trends and National Specifics of the Development of a Digital Economy. Record of the United States, India, China and the EU]. In Mezhdunarodnye protsessy [International Trends], 15(4),20-39.

Revenko, N. (2018). Novye kontury tsifrovizatsii v Rossii i za rubezhom: ekonomika sovmestnogo potrebleniia [New Digitization Profile Overseas and in Russia: Sharing Economy]. In Ekonomika. Nalogi. Pravo [Economics. Taxes. Law], 2, 103-110.

Robertson, D. (2016). Berlin Has Banned People from Renting Flats on AirbnbHere's Why. Available at: https://www.independent.co.uk/travel/news-and-advice/ 
berlin-has-banned-people-from-renting-flats-on-airbnb-heres-why-a7031811.html (accessed 22 February 2019).

Saiidi, U. (2018). Who's Competing with Uber? Available at: https://www.cnbc. com/2018/03/19/whos-competing-with-uber.html (accessed 21 February 2019).

Schleifer, T. (2018). UBER's Latest Valuation: $\$ 72$ Billion. Available at: https://www.recode.net/2018/2/9/16996834/uber-latest-valuation-72-billion-waymolawsuit-settlement (accessed 19 February 2019).

Schor, J. (2014). Debating the Sharing Economy. Great Transition Initiative. Available at: https://greattransition.org/images/GTI_publications/Schor_Debating _ the_Sharing_Economy.pdf (accessed 8 February 2019).

Schwab, K. (2017). Chetvertaia promyshlennaia revoliutsiia [The Fourth Industrial Revolution]. Moscow, E, 208 p.

Selloni, D. (2017). Co-Design for Public-Interest Services. Luxembourg, Springer, 193 p.

Shaheen, S., Cohen, A., Jaffee, M. (2018). Innovative Mobility: Carsharing Outlook. Berkley, University of California, Transportation Sustainability Research Centre, 6 p. Available at: https://cloudfront.escholarship.org/dist/prd/content/qt49j961wb/ qt49j961wb.pdf?t=pa6fa3\&v=lg (accessed 02 March 2019).

Shaheen, S., Cohen, A., Jaffee, M. (2018). Worldwide Carsharing Growth. Available at: https://escholarship.org/uc/item/49j961wb (accessed 19 February 2019).

Spartak, A.N.(2018). Sovremennyetransformatsionnyeprotsessyvmezhdunarodnoy torgovle i interesy Rossii [Current Transformation Processes in the International Trade and Interests of Russia]. Moscow, VAVT/IKAR, $456 \mathrm{c}$.

Sunil, J., Noah, Z. (2015). Policymaking for the Sharing Economy: Beyond WhackA-Mole. Toronto, Mowat Centre, University of Toronto, $26 \mathrm{p}$.

The Number of Registered Carsharing Users Exceeds 2 Million (2018). Available at: https://carsharing.de/presse/pressemitteilungen/the-number-of-registered-carsharingusers-exceeds-2-million (accessed 20 February 2019).

Trefis (2018). As a Rare Profitable Unicorn, Airbnb Appears to Be Worth at Least $\$ 38$ Billion. Available at: https://www.forbes.com/sites/greatspeculations/2018/05/11/as-arare-profitable-unicorn-airbnb-appears-to-be-worth-at-least-38-billion/\#c2df8252741e (accessed 16 February 2019).

Turo (2019). Available at: https://turo.com/about (accessed 19 February 2019).

UNCTAD (2017). World Investment Report. Investment and the Digital Economy. Geneva, United Nations Publication, 237 p. Available at: http://unctad.org/en/ PublicationsLibrary/wir2017_en.pdf 
WEF (2013). Young Global Leaders. Circular Economy Innovation \& New Business Models Dialogue. Young Global Leaders Sharing Economy Dialogue Position Paper. Geneva, World Economic Forum, 20 p. Available at: http://www3.weforum.org/docs/ WEF_YGL_CircularEconomyInnovation_PositionPaper_2013.pdf

Welch, C. (2016). New York Senate Passes Bill that Bans Short-Term Apartment Leasing on Airbnb. Available at: https://www.theverge.com/2016/6/19/11973078/nyssenate-passes-bill-banning-airbnb-entire-apartment-listings (accessed 22 February 2019).

Who Are Uber's Biggest Competitors? (2018). Available at: https://www.uberguide. net/uber-competitors/ (accessed 21 February 2019).

\title{
Феномен экономики совместного потребления в эпоху цифровизации
}

\author{
Л.С. Ревенко ${ }^{\mathrm{a}}$, Н.С. Ревенко \\ ${ }^{a}$ Московский государственный институт \\ международных отнотений (Университет) \\ МИД России \\ Россия, 119454, Москва, пр. Вернадского, 76 \\ ${ }^{6}$ Финансовый университет \\ при Правительстве Российской Федерации \\ Россия, 125993, Москва, пр. Ленинградский, 49
}

В статье исследуется зарубежный и российский опыт развития экономики совместного потребления («шеринговой» экономики). Феномен совместного потребления товаров и услуг получил импульс развития на современной волне научно-технического прогресса преимущественно за счет возможностей ичифровизации. Цифровые платформы вывели узкое явление потребительского рынка на уровень глобальной экономики и создали предпосылки не только для активизации локального обмена временно свободнылми ресурсами (материальными, трудовыми, энергетическими, рекреационными и другими), но и для трансграничного перемещения таких ресурсов. Высокая скорость распространения циирровых технологий и основанных на них бизнес-моделей, а также объективно существующий временной лаг между происходящими трансформациями и их осмыслением на теоретическом уровне создают плюралистическую картину концепциий данного явления. Критический анализ подходов экспертов из разных стран к сфере охвата экономики совместного потребления позволил выявить смещение акцентов между некоторыми традиционными экономическими категориями, что формирует поле для теоретической дискуссии. Тонкость граниџы между экономикой совместного потребления и обычной коммерческой деятельностью создает сложности регуляторной деятельности на национальном и международном уровне. Исходя 
из собственных теоретических взглядов, авторы дают характеристику основных направлений развития экономики совместного потребления, выявляют актуальные тенденции, обусловливающие происходящие в ней изменения: рост объемов рынков товаров и услуг, расширение числа совместно потребляемых объектов, ускорение операционной деятельности, оптимизация структуры доходов и расходов конечных потребителей. Выявлены преимущества и риски совместного потребления товаров и услуг.

Ключевые слова: экономика совместного потребления, циифровые платформы, оптимизация использования ресурсов, отраслевая структура рынка, контент услуг.

Научная специальность: 08.00.14 - мировая экономика. 